\title{
MANITOBA RECORDS FOR THE SHOWY ASTER
}

WALTER KRIVDA, Box 864 , The Pas, Manitoba. R9A $1 \mathrm{~K} 8$

Many different species of wild asters look alike on casual inspection because their range of variation is wide. Fortunately, the Showy Aster (Aster conspicuus $L$ indl.) differs enough from all other wild asters that it is easily recognizable in the field.

The Showy Aster is a rather spectacular wild flower with coarse, rather thick and heavily toothed leaves. The flowers are violet. Plants may reach two feet in height, in good soil. They occur in scattered clumps.

The author became familiar with this species in 1965 in Prince Albert National Park and thought it to be a western species of the Alberta foothills and ranging into Saskatchewan.

There are no previously published records of Showy Aster in Manitoba. Three local collections in The Pas area have been made within a two mile radius of one another over a 20 year period. No other plants have been seen in the area. The collections were made on an extension of the Campbell Beach on which the Highway was surveyed by the early surveyors. It is an area underlain by gravel and has good drainage. The plants were not abundant.

In 1956 specimens were collected $1.5 \mathrm{mi}$. south of town, next to a P.F.R.A. temporary camp. The plants grew in clay along the woods. Just a couple of plants occurred here (herbarium \#1797).
About $2 \mathrm{mi}$. south of the first collection, in an open field near the La Verendrye Motel (now a parking lot) a collection was made 10 August 1966 (66-185 in the writer's herbarium). Duplicates were sent out in exchange. A second collection 30 September 1966 from this site has mature seed. It is evidently frost hardy as by this date at The Pas many other plants are frozen. This collection looked fresh.

A third collection 1 August 1976 (\#76-555) was less than $0.5 \mathrm{mi}$. from number 66-185 taken 10 years previously. In mid-August 1983 in the area where 76-555 was collected an extensive colony was found to exist in the heavy stand of poplar. Specimens were collected for exchange.

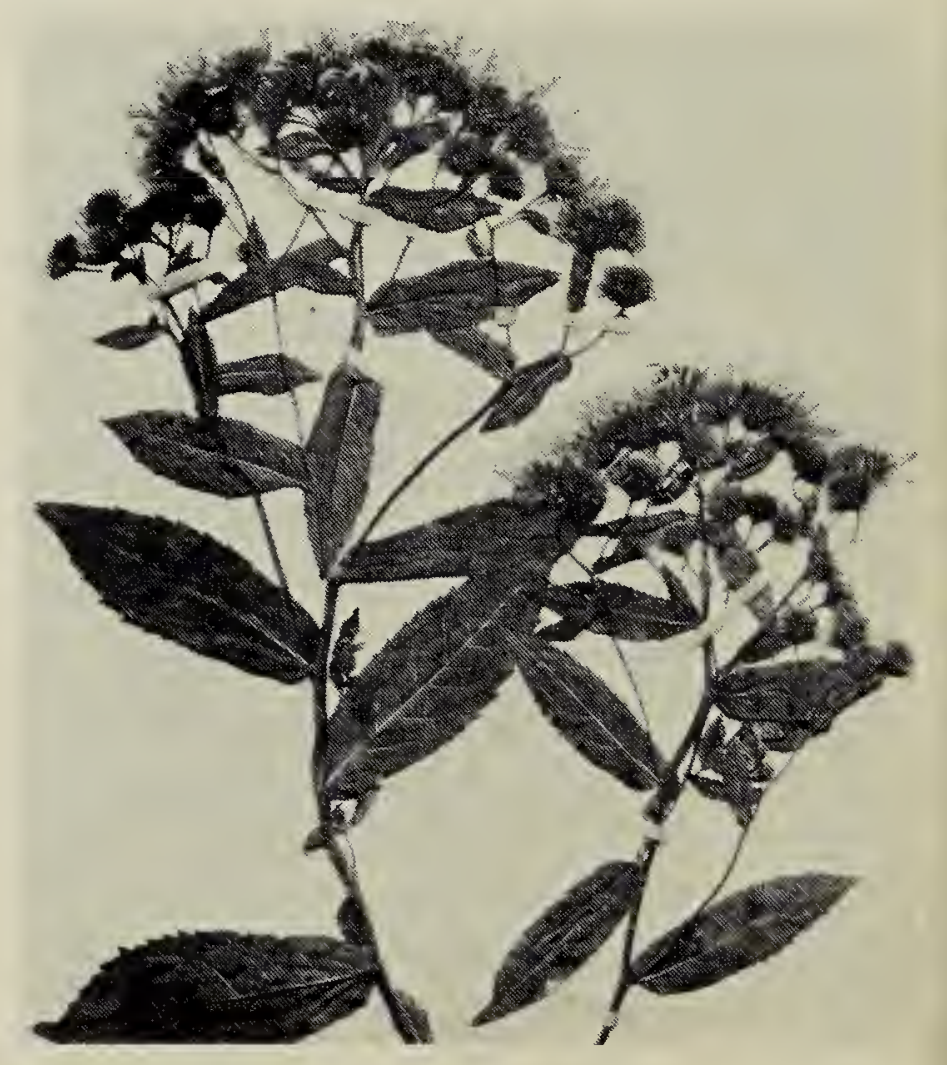

Showy Aster

Terry Dartnell 